\title{
Teachers' autonomy deconstructed: Irish and Finnish teachers' perceptions of decision-making and control
}

European Educational Research Journal

(C) The Author(s) 2019 Article reuse guidelines: sagepub.com/journals-permissions DOI: | 0.1 | 77//474904 | 19868378 journals.sagepub.com/home/eer

@SAGE

\author{
Maija Salokangas \\ Wieland Wermke \\ Department of Education, Uppsala University, Sweden
}

\section{Gerry Harvey}

School of Education, University of Dublin, Trinity College, Ireland

\begin{abstract}
Teacher autonomy has been a popular topic of investigation over the past decades. This article contributes to the debate by casting light on Irish and Finnish teachers' perceptions of their professional autonomy, drawing from teacher interviews conducted in both countries. The intersection of newly introduced curriculum reforms, differing education governance models and differing control regimes make Ireland and Finland fertile points of comparison. Teacher autonomy is understood in this article as a multidimensional and context-dependent phenomenon, and the conceptualisation is presented in an analytical matrix applicable to comparative research. Findings indicate that teachers in both countries consider themselves very autonomous in their classroom practice and in their educational decisions overall. However, where much of the school-level decision-making in Finnish schools concerning educational, social and developmental issues tends to be in the hands of teachers (either collegially or as individuals), in Irish schools the senior management, and especially the principal, is reportedly more involved. Possibly the greatest difference is the ways in which teachers' work is controlled, and in how teachers perceive it; Finnish teachers report intensified external control from the civil society, whereas on top of parental pressures Irish teachers report also increasing pressures from the state agencies.
\end{abstract}

\section{Keywords}

Comparative research, decision-making, control, Ireland, Finland, teachers' work, autonomy 


\section{Introduction}

Teacher autonomy has been a topic of heated debate in public discourses as well as an increasingly popular topic of investigation over the past few decades. High degrees of teacher autonomy have been associated with positive effects, as autonomous teachers are proven to be efficient in and satisfied with their work, with positive perceptions about their working climate in which they feel empowered (Parker, 2015; Wilches, 2007). Furthermore, autonomous teachers tend not to burn out or leave their jobs as easily as their more restricted colleagues (Parker, 2015; Wilches, 2007). Positive links have also been drawn between teacher autonomy and student outcomes; the ways in which Finnish teenagers' success in PISA is partially explained by the country's autonomous teaching force is an apt example (Sahlberg, 2011). This line of reasoning is also prevalent in the Teachers Matter movement, which argues for the importance of teachers in student performance (Hattie, 2011). Often drawing from this line of reasoning, over the past decades teacher autonomy has been used as an argument for varied school improvement efforts. A case in point is the school autonomy movement, which promotes increased school autonomy, often using the positive connotations of teacher autonomy as an argument, despite the lack of direct link between the two (Salokangas and Ainscow, 2017; Salokangas and Chapman, 2014).

This article contributes to the debate by casting light on Irish and Finnish teachers' perceptions of their professional autonomy. As such, it investigates the nature of teachers' work in these two rather different national contexts by making comparisons concerning the nature of teachers' work. The article draws from teacher interviews conducted in both countries. The study is part of a wider European research project concerning teacher autonomy across different countries, and findings concerning German and Swedish teachers' scope of action have been reported elsewhere (Wermke et al., 2019).

As recent comparative research focussing on teacher autonomy has revealed, nation-specific ideas of a profession can be strongly rooted in the perceptions professionals have of themselves, and in what autonomy means for them (Errs and Kalmus, 2018; Paulsrud and Wermke, 2019), and it is therefore worthwhile to examine how teachers in different national contexts perceive their autonomy. Comparisons between Irish and Finnish teachers in particular are justifiable and worthwhile for three main reasons. Firstly, both countries have recently introduced curriculum reforms: Junior Cycle reform (Department of Education and Skills, 2015) in Ireland and Curriculum Reform in Finland (Finnish National Agency for Education, 2018). Both reforms draw from social constructivist ideas of teaching and learning, emphasising the role of the teacher as a facilitator for learning (Saari et al., 2017). It is worthwhile to note that in justifying the Junior Cycle reform, the Finnish education system was constantly referred to as an example of international best practice (e.g. Humphreys, 2014). In Finland the national core curriculum was published in 2014, which set in motion a school- and municipality-level curricular localisation process (Soini et al., 2018). The local curricula, developed by teachers in a collaborative process, was approved in 2016, and applied in schools from August 2016 onwards. Although Finnish teachers play an important role in developing the local curriculum, due to the nature of the new curriculum, curricular analysis points to the diminishing role of the teacher in the learning process as the facilitator of learning, and the potential effects these changes have on Finnish teachers' work (Erss, 2017). In Ireland, Irish second-level students traditionally study a wide range of subjects via content-rich syllabi which reward students who have strong rote-learning abilities and perform well in high-stakes terminal examinations. The Junior Cycle reform reduced the significance of a national exam at lower secondary level by introducing continuous assessment conducted by teachers (National Council for Curriculum and Assessment, 2014). This radical change in assessment practices, which had direct 
implications for teachers' work, was widely debated in popular as well as academic fora. As Murchan and Shiel put it:

The changes in assessment, though not universally welcomed by teachers in Ireland, are intended to place a stronger focus on assessment for learning (formative assessment) . . Moreover, it is intended that the Junior Certificate Profile of Achievement will recognise a wider range of learning while reducing the focus of the final examination. (2017: 147)

Recent studies have revealed that, as is common in curriculum reform processes, some mismatch between the intended and interpreted curriculum has occurred (Prendergast and Treacy, 2018).

Secondly, and strongly related, these two countries are examples of different control regimes (Wermke and Höstfält, 2014). In Ireland, the high-stakes exams at the end of Junior Cycle with an emphasis on measurable learning outcomes and external marking procedures by the State Examinations Commission, combined with publicised school league tables as well as varied school inspections practices, are features often associated with high-stakes accountability regimes (Prøitz et al., 2017). In comparison, Finnish teachers operate in a more trust-based control regime, with no national published exam results or school inspection at post-primary level (Mølstad, 2015). The longue durée of national education and social policy as well as traditions of curriculum development have shaped existing education governance and control regimes, which have been demonstrated to reflect division between curriculum tradition prevalent in many Anglo-American countries, and a German/European continental tradition of Didaktik (Hopmann, 2008, 2015; Karseth and Sivesind, 2010; Lundgren, 2006; Prøitz et al., 2017). Such national ideas and values about schooling can be explained to reflect input or outcome governance regime (Benner, 2009; Hopmann 2003; Wermke et al., 2019; Wössmann, 2007). In input regimes teachers are considered to be civil servants holding great shared decision-making capacity, and being subject to little if any formal forms of external control imposed upon them from outside the teaching profession. Of our cases, Finland represents this type. Outcome regimes again impose control upon teachers from the outside through, for example, district-level administration, state agencies or exam boards. As such, high-stakes national exams and other forms of accountability paired with a prescriptive curriculum are important features of outcome regimes and therefore resonate strongly with the Irish case. These traditions define teachers' roles quite differently, and, as has been argued recently (Verger and Parcerisa, 2017), varied accountability mechanisms associated with different control regimes can have mixed and unexpected effects on schooling and on teachers' work in particular. All of which offers a fruitful starting point for examining teacher autonomy in Ireland and Finland.

Thirdly, governance of the two education systems is considerably different. Whereas Finnish schools operate mostly under the municipality structure, Irish schools operate in a traditionally highly centralised structure under a variety of patrons (religious and non-religious). The Irish postprimary education sector comprises secondary, vocational, community and comprehensive schools. Secondary schools are privately owned and managed. Vocational schools are state-established and administered by Education and Training Boards (ETBs), while community and comprehensive schools are managed by Boards of Management of differing compositions. To cater for an increasingly secularised society a new model, Educate Together, was introduced about a decade ago, which is currently in charge of 13 second-level schools. However, the involvement of religious patrons remains considerable to date, as just under $50 \%$ of post-primary schools are classified as Catholic (Byrne and Devine, 2018).

The intersection of the differing control regimes, newly introduced curriculum reforms, and differing education governance models make Ireland and Finland fertile points of comparison. In what follows, we first present our definition of teacher autonomy as a multidimensional 
context-dependent phenomenon. In data collection and analyses, we draw from established conceptualisations of teacher autonomy, some of them published earlier in this journal (Cribb and Gewirtz, 2007; Gewirtz and Cribb, 2009; Ingersoll 1996, 2003) and our recent conceptual work (Wermke et al 2019), and present our conceptualisation of teacher autonomy in the form of an analytical matrix. Then findings from both countries are discussed thematically, with a focus first on teachers' decision-making, followed by an analysis of control in both countries. Finally, the implications for research and policy are discussed.

\section{Theoretical vantage point I: Teacher autonomy as decision- making and control}

The starting point for our conceptualisation is Richard Ingersoll's $(1996,2003)$ work concerning power distribution and control in schools, which has helped us to conceptualise teacher autonomy around teachers' decision-making capacity and the ways in which their decision-making is controlled. Although his theorisation is based on empirical work carried out in the USA, owing to its focus on organisational rather than nation-specific contexts, the central idea provides applicable conceptual tools to different national contexts and comparative studies.

Focussing firstly on decision-making, in his early work Ingersoll (1996) pointed out that teachers often have considerable responsibilities in terms of the pedagogical and social dimensions of their work; their students' learning, welfare and socialisation. However, high levels of responsibility do not always correlate with teachers having control over key issues concerning their work. Following his argument (Ingersoll, 2003) it is thus important to distinguish division of labour as distribution of responsibility and control. As we have argued elsewhere: 'delegating decision-making on less important issues is often used as a subtle centralisation of power where employees experience participation in organisational control that in reality does not exist' (Wermke et al, 2019).

Therefore, in order to capture the nature of teacher autonomy, it is important to investigate how and by whom autonomy is controlled. Teachers may, for example, operate under a prescriptive curriculum which sets tight boundaries concerning pedagogical decisions, whereas school-level policy and national legislation may give them considerable scope concerning, for example, the social side of their work. Control may be imposed upon teachers by different actors. For example, some areas of teachers' work may be inspected regularly by school administration, or perhaps by an external inspector. In some instances inspections may be less influential for teachers' decisionmaking; however, other external inspections may have considerable effects on teachers' work. In order to capture such nuances in research, it is important to acknowledge the different dimensions of teachers' work.

\section{Theoretical vantage point 2: Teacher autonomy as a multidimensional phenomenon}

Following this, we consider teacher autonomy to be a multidimensional context-dependent phenomenon. Here we draw on a body of literature that has investigated the phenomenon empirically (Frostensson, 2015; Ingersoll, 2003; Salokangas and Ainscow, 2017; Wermke and Forsberg, 2017; Wermke and Höstfält, 2014; Wermke et al., 2019) and offered useful theoretical considerations of the problem (Cribb and Gewirtz, 2007; Gewirtz and Cribb, 2009; Lubienski, 2003). Teachers' work is complex, comprising different types of tasks including educational, social and administrative tasks (Ingersoll, 2003). This relates to Cribb and Gewirtz's (2007) and Gewirtz and Cribb's (2009) 
Table I. Teacher autonomy as a multidimensional phenomenon.

\begin{tabular}{|l|l|l|l|l|}
\hline \multicolumn{1}{|c|}{ Domain } & $\begin{array}{l}\text { Education } \\
\text { (planning, teaching, } \\
\text { assessment) }\end{array}$ & $\begin{array}{l}\text { Social } \\
\text { (discipline, grouping } \\
\text { of students) }\end{array}$ & $\begin{array}{l}\text { (pevelopment } \\
\text { development) }\end{array}$ & $\begin{array}{l}\text { Administration } \\
\text { (timetables, } \\
\text { resource allocation) }\end{array}$ \\
\hline $\begin{array}{l}\text { Classroom } \\
\text { (in relation to students } \\
\text { and taught content) }\end{array}$ & & \multicolumn{3}{|l|}{} \\
\hline $\begin{array}{l}\text { School } \\
\text { (in relation to } \\
\text { management, } \\
\text { colleagues, parents) }\end{array}$ & perceived autonomy and levels of teachers' & \\
\hline $\begin{array}{l}\text { Profession } \\
\text { (in relation to actors } \\
\text { in the wider education } \\
\text { system and society) }\end{array}$ & & & & \\
\hline
\end{tabular}

notion of autonomy domains. Indeed, where much of teachers' work is educational, dealing with pedagogical questions concerning, for example, planning, teaching and assessment, teachers' work also comprises other, often overlooked domains, such as social, administrative and developmental tasks. With social domain we refer to teachers' tasks that relate to, for example, managing student behaviour, grouping students, or establishing and enforcing social rules in the school. Administrative domain again refers to bureaucratic tasks concerning school operations. The extent to which teachers can contribute to timetables or allocation of resources are examples of the administrative questions that affect teachers' work. Developmental domain refers to the future planning of the school as a whole, or certain areas of it. What future directions the school is taking, and the extent to which teachers may opt in (or out) of professional development, are examples of such developmental questions (Author, 2014). In our analytical device, these four domains of teachers' work appear vertically as columns in the matrix (see Table 1).

In addition to different domains, teacher autonomy in also a layered phenomenon, as teachers operate as individuals as well as members of professional communities and groups within their schools and more widely. This relates to Cribb and Gewirtz's (2007) and Gewirtz and Cribb's (2009) notion of loci of autonomy and control. For example, teachers as a collective group, such as teachers of a particular subject, may possess a certain scope of action as a collective; however, this does not necessarily reflect the realpolitik of their circumstances within their schools and classrooms. Further adding to the complexity of the phenomenon, teachers' work takes place in particular national and local contexts. For example, national and local education policy and governance, economic circumstances and the type of schools in which teachers work all have direct or indirect effects on what teachers can and cannot do. To capture these complexities we propose three dimensions of teacher autonomy. The classroom dimension refers to the scope of action teachers have in their classrooms as individual professionals. This relates to Frostensson's (2015) conception of teachers' individual autonomy and Wermke's \& Höstfält's (2014) idea of service autonomy, and comprises questions concerning, for example, teachers' choice of taught content and methods. 
Secondly, the school dimension relates to Frostensson's (2015) idea of the faculty dimension. Here school is the arena in which teacher autonomy is formed and teachers are considered as a group or groups of professionals. Questions concerning collegiality and co-operation, as well as teachers' relations with parents and the local community, may be of interest. Finally, the professional dimension concerns teachers as a wider group of professionals. Questions such as how the teaching profession negotiates and bargains in wider society - for example, through unions - here come into play.

The conceptualisation is organised in the matrix (Table 1). The matrix brings the conceptual framework together by placing the different dimensions of teacher autonomy (educational, social, administrative, developmental) on the vertical columns and the layers of the teaching profession (individual, school, profession) on the horizontal rows. We utilise the matrix later to present summaries of data.

The matrix contains 12 different cells (see Table 1), which enable the analysis of data on teacher autonomy. As our analysis later shows, this is particularly helpful for comparative studies. The borders of the cells might not be straightforward in teachers' actual practice, and the cells might split processes that span different dimensions of teacher autonomy. For example, teachers' contributions to school-level policies may have administrative, educational, social or developmental functions. This is exactly why we argue that the matrix is applicable, as it helps to separate and analyse the conflated phenomena of autonomy and show relationships between different dimensions and levels.

The matrix can be utilised to analyse both teacher autonomy and control. We demonstrate this later in the article as we present the findings. Utilising the matrix as an analytical device makes various patterns of autonomy and control visible. Following Ingersoll's (2003) argument, the device can also be used to compare different configurations of how teachers in various contexts experience professional decision-making and control. Teachers have been asked which of the dimensions they perceive to have individual, collegial or professional discretion or which other actors in the school system have power to make significant decisions in different dimensions. As such, the matrix helps to reveal multiple possible configurations. For example, autonomy in the classroom, both social and educational, might present a greater challenge for teachers in one context than developmental and administrational autonomy. Then, teachers in some contexts may experience autonomy in certain domains in their classroom, but in school-level work their autonomy may be restricted. Or the teaching profession's autonomy in one context is extended, but both in schools and in classrooms is restricted. In another context, teachers as a professional group may not experience autonomy due to the influence of different actors in the school system, but, at the school level, individual teachers have extended autonomy. The device helps all these examples to become visible, and as such offers a valuable tool for comparative studies.

\section{Methods}

As established earlier, teachers' work takes place in layered contexts in which teachers operate as individuals as well as members of professional groups. In addition to such often-presumed heterarchical collaborative scenarios, teachers operate within hierarchical organisational structures, involving varied dynamics of power and influence between members of staff. Who in such complex social settings can make decisions concerning central issues of teachers' work and the school is a question that remains at the heart of empirical teacher autonomy investigations. The extent to which teachers are able to contribute to important decisions concerning their work, or whether they are perhaps left tinkering around with less relevant issues, are important questions for understanding teacher autonomy. Drawing on Ingersoll's (2003) work, we posed three questions: 
1. According to teachers, what are the most important decisions in their work and concerning the functioning of the school?

2. According to teachers, who makes these decisions (the principal, teachers, students, state agencies, parents, etc.)?

3. How are decisions monitored and followed up and who ensures that decisions are implemented correctly?

These questions helped us to develop our interview schedules, and they set the frame of teacher autonomy around decision-making and control.

The findings reported here draw from a qualitative study involving teacher interviews conducted in Irish and Finnish schools. The data from Finland consists of 14 lower secondary school teacher interviews. The teachers involved include subject teachers, special education needs teachers, and career councillors, all of them teaching lower secondary students aged 13-16 years.

The two schools from which data were gathered - Koivula School and Kuusikko School (pseudonyms) - are located in the municipality of Helsinki and, as is increasingly common in Finland, are both unified comprehensive schools offering primary and lower secondary school provision. As is also common for urban Finnish schools, both offer a specialised subject for one class per year group at the upper secondary level. Worth a mention is that when asked to describe their schools, 12 out of 14 interviewees described their schools as 'ordinary', referring to student intake. Mainstream student intake in both schools is mixed socio-economically and in terms of ability, and comprises local residents. However, the specialist classes in both schools attract students with higher grades, and in order to get admitted they sit an entrance exam - yet another common feature of school markets in Finland, where, in urban areas especially, students are increasingly stratified into classes according to ability (Kosunen, 2014).

In Ireland, 17 teacher interviews were conducted in 3 post-primary schools in the greater Dublin region. The sample of schools selected was chosen to reflect the diversity of patronage which is a unique characteristic of the Irish education system. Seven of the interviews were conducted in Ashbrook Community College, a co-educational school under the patronage of the local municipal body which is one of 16 regional Educational and Training Boards (ETBS). The other two schools are voluntary single sex boys' schools and operate under religious patronage. St Aidan's School has a Delivering Equality of Opportunity in Schools (DEIS) ${ }^{1}$ status, serving a considerable proportion of students with varied levels of disadvantage, while Augustus College students come mainly from affluent areas in south Dublin. The 17 teacher interviewees were demographically diverse in terms of age and gender, and they taught a wide range of subjects and had different levels of management duties in their schools.

All data was recorded and transcribed. The Finnish data was translated into English in order to make it accessible to all research team members and for the purposes of cross-country comparisons. The conceptual tools presented earlier were utilised in data analysis, where decision-making and control became central themes, and different dimensions (educational, social, administrative and developmental) and layers (individual, school and profession) became subthemes. The coding process reflected these themes and was conducted using Atlas TI qualitative data analysis software. The same codes were used for the interviews for both countries; these codes enabled the categorisation of data not just into the domains and levels, but also addressed the three questions in terms of decision-making and control, as outlined earlier in the methods section of the article.

\section{Findings}

In what follows we offer a thematic presentation of data, focussing firstly on teachers' decisionmaking capacity, and secondly on the ways in which their work is controlled. Cross-country 
comparisons are offered in each section. Summaries of findings are presented in tables and further illustrated through presentation of raw data.

\section{Teachers' decision-making}

Generally, both Finnish and Irish teachers consider themselves considerably autonomous in their classroom practice and overall in their educational decisions. However, where much of the schoollevel decision-making in Finnish schools (Table 2) concerning educational, social and developmental issues tends to be in the hands of teachers (either collegially or as individuals), in Irish schools the senior management, and especially the principal, are more involved (Table 3).

When it comes to the educational domain, teachers in both countries consider themselves quite autonomous in their classroom practice. They refer to the curriculum as the document guiding their work, but they consider themselves to be independent in terms of how they teach and what teaching materials they use. Such independence is mostly reported as a positive quality of their work; however, some teachers in both countries also raised the independence of individual teachers as a challenge, particularly when it comes to colleagues who operate a 'closed door policy' and do not actively engage with colleagues. The key difference between Irish and Finnish teachers' pedagogical practice concerns student assessment. Finnish teachers were well used to assessing their students' learning: 'Assessment is what guides our work somewhat, because that's something that has to be taken care of always. And it should be transparent, so parents can appeal if they are not happy' (Helena, biology and home economics teacher, Koivula School). Unanimously, Finnish teachers considered student assessment as part of their professional practice. However, they were also very keen to highlight that assessment was a considerable source of stress, in particular because it is

Table 2. Decision-making in Finland.

\begin{tabular}{|l|}
\hline $\begin{array}{l}\text { Decisions } \\
\text { made by: }\end{array}$ \\
\hline $\begin{array}{l}\text { Individual } \\
\text { teachers }\end{array}$ \\
\hline $\begin{array}{l}\text { Teachers } \\
\text { collectively }\end{array}$ \\
\hline Principal \\
\hline $\begin{array}{l}\text { Actors } \\
\text { outside school }\end{array}$ \\
\hline
\end{tabular}

\begin{tabular}{|c|c|c|c|c|}
\hline Level & $\begin{array}{l}\text { Education } \\
\text { (planning, } \\
\text { teaching, } \\
\text { assessment) } \\
\end{array}$ & $\begin{array}{l}\text { Social } \\
\text { (discipline, } \\
\text { grouping of } \\
\text { students) }\end{array}$ & $\begin{array}{l}\text { Development } \\
\text { (professional } \\
\text { development) }\end{array}$ & $\begin{array}{l}\text { Administration } \\
\text { (timetables, } \\
\text { resource } \\
\text { allocation) } \\
\end{array}$ \\
\hline $\begin{array}{l}\text { Classroom } \\
\text { (in relation to } \\
\text { students and } \\
\text { taught content) }\end{array}$ & & & & \\
\hline $\begin{array}{l}\text { School } \\
\text { (in relation to } \\
\text { management, } \\
\text { colleagues, } \\
\text { parents) }\end{array}$ & & & & \\
\hline $\begin{array}{l}\text { Profession } \\
\text { (in relation to } \\
\text { actors in the } \\
\text { wider education } \\
\text { system and } \\
\text { society) }\end{array}$ & & & & \\
\hline
\end{tabular}


Table 3. Decision-making in Ireland.

\begin{tabular}{|l|}
\hline Decisions made by: \\
\hline $\begin{array}{l}\text { Individual } \\
\text { teachers }\end{array}$ \\
\hline $\begin{array}{l}\text { Teachers } \\
\text { collectively }\end{array}$ \\
\hline Principal \\
\hline $\begin{array}{l}\text { Actors outside } \\
\text { school }\end{array}$ \\
\hline
\end{tabular}

\begin{tabular}{|c|c|c|c|c|}
\hline Domain & $\begin{array}{l}\text { Education } \\
\text { (planning, } \\
\text { teaching, } \\
\text { assessment) }\end{array}$ & $\begin{array}{l}\text { Social } \\
\text { (discipline, } \\
\text { grouping of } \\
\text { students) }\end{array}$ & $\begin{array}{l}\text { Development } \\
\text { (professional } \\
\text { development) }\end{array}$ & $\begin{array}{l}\text { Administration } \\
\text { (timetables, } \\
\text { resource } \\
\text { allocation) } \\
\end{array}$ \\
\hline $\begin{array}{l}\text { Classroom } \\
\text { (in relation to } \\
\text { students and } \\
\text { taught content) }\end{array}$ & & & & \\
\hline $\begin{array}{l}\text { School } \\
\text { (in relation to } \\
\text { management, } \\
\text { colleagues, } \\
\text { parents) }\end{array}$ & & & & \\
\hline $\begin{array}{l}\text { Profession } \\
\text { (in relation to } \\
\text { actors in the } \\
\text { wider education } \\
\text { system and } \\
\text { society) }\end{array}$ & & & & \\
\hline
\end{tabular}

often conducted individually and is loaded with high expectations from students and parents. This is how one Finnish teacher describes how she 'shields' herself from high pressures:

Parents nowadays are so much more aware and the parents that really care about their child's life, they can meddle. That's why you have to keep the assessment books for ten years. I actually have every book from 25 years, I haven't gotten rid of any of them. You might have to justify your grading even after five years. (Helena, biology and home economics teacher, Koivula School)

In Ireland, where the national Leaving Certificate examinations dominate the educational discourse, teachers explained their role in assessment quite differently. At the time of data collection, assessment was an issue that Irish teachers were particularly vocal about as the recent curricular reform had shifted practices at the Junior Cycle level, making teachers more involved in assessing their students' learning. The data shows that Irish teachers do not wish to assess the work of their own students and passionately believe that assessment conducted by the State Examinations commission completely independent of classroom teacher assessment is preferable to alternatives:

I don't think it's a good idea and I think the whole idea of an exam is that it's looked at anonymously, it's looked at by somebody who has no like day-on-day interaction, no social connection, no known connection to a child and I think regardless of professionalism, when you work with the same kids day in, day out for years, it makes it, very difficult to, I think, independently assess those children. (Kieran, English and geography teacher, St Aidan's School) 
I think it [teacher assessing the learning of their students] is a terrible idea. It doesn't in any sense make any sense. I mean, for me to grade my own students is giving an autonomy that is impractical, unrealistic. (Aidan, history and English teacher, Augustus College)

The phased introduction of teachers assessing their own students in all Junior Cycle subjects was spread out over a few years, with completion of all subjects introduced by September 2019 (National Council for Curriculum and Assessment, 2015). The paradigm shift in the collective understanding of what is effective assessment is reinforced by the teacher training colleges and the national inspectorate, who look for a diverse range of assessment strategies with a particular emphasis on assessment for learning when conducting lesson evaluation of trainee and qualified teachers. Time will tell if this shifts Irish teachers' perceptions of assessment. However, the historical legacy of the traditional approach to State examinations for Irish teachers is likely to endure for some time, as highlighted by the strong sense of conviction and unorthodox understanding of teacher autonomy evident in the above quotes.

In terms of the social side of teachers' work, overall teachers reported substantial collaboration and shared decision-making in social decisions at school level. Teachers liaise with other subject teachers, special needs teachers and teaching assistants almost on a daily basis, and engagement with multi-professional teams including, for example, educational psychologists, school counsellors, speech therapists, and/or social services was reported, especially in relation to the pastoral care of students. The following quote by an experienced Irish teacher encapsulates the developments in both countries which have, according to both Irish and Finnish teachers, contributed to an increase in shared decision-making over social matters:

How we operate schools has changed significantly. In my early years where I would have been a tutor in class, it would have been very much kind of disciplinary role. And the whole pastoral side of student life was not as well developed as it is now. (Kathleen, history and geography teacher, Ashbrook Community College)

In addition to pastoral care, teachers in both countries also reported teachers' efforts in writing school-based behaviour policy. In most schools such work was conducted by a team of teachers, who consulted other staff in various ways. Such school-based behaviour policies were based on national guidelines and their legal framework, and these localised versions gave teachers a practical toolkit for behaviour management within their classrooms, during break times, school trips, etc.:

We have a code of behaviour, so the idea is that it starts with the teacher, that we've a couple of different stages that we would go through and we would keep working up through those stages. For example, maybe a minor misbehaviour in class, there might be something like a note in the journal and some punishment work that might have to be signed that goes with it and if that's not done then you move up and the stage up from that maybe is like a personal detention, like a lunchtime detention. If that's not done, then it has to move on, you have to escalate it so it escalates up to like after-school detention or report to the year-head and beyond that, like, those stages then keep moving up so the year-head would maybe phone home or management gets involved or whatever. So, there are kind of very clear steps that you can follow but again that falls on the teacher to be consistent. (Kieran, English and geography teacher, St Aidan's School)

As these policies required school-wide application of rules and regulations, they limited individual teachers' decision-making capacity. However, this was a limitation that teachers in both countries embraced. School-wide unified behaviour policies and disciplinary practices were considered an important measure of security for both teachers and students alike in maintaining consistency and 
principles of fairness in dealing with student behaviour. Teachers could apply collaboratively decided rules and regulations, which, on the occasion of conflict and possible disagreement with parents, was a highly valued resource. However, as the Irish teacher explains above, it was up to individual teachers to follow these policies through.

In both countries the degree to which teachers were involved in decision-making concerning student grouping varied. Some schools in both countries gave teachers wide scope of action whereas other schools centralised such decision-making to the management team and principal. For example, if timetables allowed, in Koivula School teachers held collegial autonomy over social matters as they decided together how their students were grouped for lessons:

I: Do you divide students between the math teachers then? You discuss it between yourselves and then decide which student groups would work or . . .?

R: Yes, we divide them [students] all by ourselves.

I: So you don't need to have a principal there, sitting in a meeting?

R: No, we don't . . . the groups were originally divided, probably in alphabetical order, and then we conducted some changes between them. So the basis comes from principal, but we did some modification by ourselves. (Elina, maths and science teacher, Koivula School)

This is peculiar, as officially the school was not tracking students according to ability. However, after teachers' modifications the groups could be identified as higher-performing and lower-performing classes. In order to justify their decisions, teachers offered social and pedagogical reasons: for example, maintaining a peaceful working environment by breaking up certain student friendship groups was a common justification. However, teachers also openly admitted that dividing groups according to ability allows teachers to better focus their teaching as there is less need for differentiation. From the perspective of inclusive practice, an idea to which the school was strongly committed, such decisions are harder to justify. In Augustus College, in Ireland, similar practices were in place as teachers streamed students to ability groups:

Yeah, so we stream them ourselves. So, we would get the results back after a staff meeting at the beginning of the year say and all of us would sit down together and we would come up with you know, who is going to be in what class and that. So, we would stream them ourselves, yes. (Grainne, Irish and French teacher, Augustus College)

However, both Irish and Finnish teachers would also be excluded from such decisions. As a Kuusikko School teacher explains, they simply received student lists from the school management and as such were denied the collegial autonomy that their colleagues in Koivula School had:

I: $\quad$ Is there an area in which you wish you had more influence as a teacher?

$\mathrm{R}$ : Well maybe some things relating to student grouping. Almost every special education student is integrated in a general group ... We might have a student who has been in Finland for a year, and they come to ninth grade, so one year in preparatory class and then they have to finish, so maybe you could think those situations more.

I: Where are those decisions made?

R: Well they just, the principal just, in a way, puts them somewhere and they just go there. (Leila, Swedish teacher, Kuusikko School)

In summary, social decisions were an area in which between-country differences were not considerable, but obvious between-school differences occurred. 
Where Irish and Finnish teachers' work differed to some extent was in relation to how they felt their views were consulted, and what opportunities they had to contribute to the developmental side of the school work. Finnish teachers felt that they were very much consulted and involved in the developmental work that was going on in their schools and at municipality level. Depending on the school, this could, for example, have meant the school taking new directions in emphasising a subject area, becoming a specialist school in, for example, arts, or perhaps in introducing new ways of working for the whole school. As an example of an initiative concerning a number of schools, the municipality of Helsinki introduced a digitalisation initiative to enhance the use of technology (Saari and Säntti, 2018). Teachers had mixed feelings about the initiative, as on the one hand it was considered to be important and timely, but on the other hand it was felt that it was poorly resourced and overly ambitious. At the schools we visited, teachers were involved in the planning and consulting process, finding solutions suitable not only for their particular situations, but also collegially with teachers from other schools across the municipality at the municipality level:

The big thing now is the digitalisation, or 'Digi Leap' as it's known here. I've been sitting in this group involving digi coordinators from schools across the city. I felt like a voice of reason there, a lonely voice in the desert. (Ritva, Finnish teacher, Kuusikko School)

Digitalisation initiatives also kept Irish teachers busy; however, where Finnish teachers reported involvement in both school-level and municipality-level developmental activities, Irish teachers were mostly occupied with school-level implementation. One teacher explained to us how the information and communications technology (ICT) coordinator role at Ashbrook was a voluntary position involving school-level ICT coordination:

[I]t doesn't increase the salary for me, completely voluntary. I was approached by the Principal and she asked me would I do it and I said ok . . . it's such a big job that you'd probably need more than just myself. (Enda, metalwork and woodwork teacher, Ashbrook Community College)

The developmental domain for Irish teachers, be it at classroom, school or professional level, is not an area in which they perceive they have an ample degree of autonomy, as these decisions are considered the responsibility of other educational stakeholders. The principal is seen as the primary decision-maker in conjunction with the school's governing body, be that the school's Board of Management or Patronage body. Overall, strong interest and active involvement in professional development are considered characteristics of a strong teaching profession, a feature that was more obviously prevalent amongst the Finnish than Irish interviewees.

In terms of administrative decisions, both Irish and Finnish teachers expressed rather similar experiences of limited autonomy. They felt that they spent a considerable amount of time completing paperwork and reporting various matters. However, when it came to actual administrative decision-making concerning issues that affect their work, such as allocation of resources and timetables, teachers felt that key decisions were largely outside their control.

I: Is there an area of your work where you would feel your hands are tied, where you wish you could use more of your own authority?

R: Well um . . Well, of course the schedules, but in a way, my wishes have been heard quite a lot in that as well, so having theoretical subjects in the morning and arts and crafts in the afternoon. (Sara, special needs teacher, Kuusikko School)

The kind of influence illustrated in the above Finnish teacher's comment exemplifies responses from both countries. Both Finnish and Irish teachers talked about informal ways to influence 
administrative decision-making, as in 'having informal conversations with the principal'. In some schools consultation processes were in place in which teachers were invited to express their views; however, overall administrative decisions in both countries are seen as the primary responsibility of the principal. As one Irish teacher explained: 'So, I can take them [a group of students] out, but I have to get permission from the principal' (Grainne, Irish and French teacher, Augustus College). In both countries, teachers with special roles, such as deputy principals and assistant principals, may have more influence over such matters than teachers with no special posts. However, as far as teachers are concerned the ultimate administrative responsibility in both countries lies with the principal.

\section{Control}

The most striking differences between the two countries can be seen in the ways in which teachers' decision-making is controlled. Where Finnish teachers are free from formal control mechanisms imposed upon their work, their Irish colleagues reported varying intensifying pressures. In what follows, this section discusses how teachers perceive control. When it comes to less formal control, such as parental expectations, both Irish and Finnish teachers

Table 4. Control in Ireland.

\begin{tabular}{|l|}
\hline Control : \\
\hline High intensity \\
\hline Low intensity \\
\hline No control \\
\hline
\end{tabular}

\begin{tabular}{|c|c|c|c|c|}
\hline $\begin{array}{l}\text { Domain } \\
\text { Level }\end{array}$ & $\begin{array}{l}\text { Education } \\
\text { (planning, } \\
\text { teaching, } \\
\text { assessment) }\end{array}$ & $\begin{array}{l}\text { Social } \\
\text { (discipline, } \\
\text { grouping of } \\
\text { students) }\end{array}$ & $\begin{array}{l}\text { Development } \\
\text { (professional } \\
\text { development) }\end{array}$ & $\begin{array}{l}\text { Administration } \\
\text { (timetables, } \\
\text { resource allocation) }\end{array}$ \\
\hline $\begin{array}{l}\text { Classroom } \\
\text { (in relation to } \\
\text { students and } \\
\text { taught content) }\end{array}$ & $\begin{array}{l}\text { High-stakes } \\
\text { exams, } \\
\text { State } \\
\text { Examinations } \\
\text { Commission }\end{array}$ & & & \\
\hline $\begin{array}{l}\text { School } \\
\text { (in relation to } \\
\text { management, } \\
\text { colleagues, } \\
\text { parents) }\end{array}$ & $\begin{array}{l}\text { Inspectorate, } \\
\text { high stakes } \\
\text { school } \\
\text { inspections and } \\
\text { frequent school } \\
\text { visit }\end{array}$ & $\begin{array}{l}\text { Department } \\
\text { of Education } \\
\text { and Skills; } \\
\text { legislation/ } \\
\text { circulars } \\
\text { Inspectorate; } \\
\text { external and } \\
\text { School Self- } \\
\text { Evaluation } \\
\end{array}$ & & $\begin{array}{l}\text { All schools } \\
\text { receive state } \\
\text { funding but in } \\
\text { varying amounts }\end{array}$ \\
\hline $\begin{array}{l}\text { Profession } \\
\text { (in relation } \\
\text { to actors in } \\
\text { the wider } \\
\text { education } \\
\text { system and } \\
\text { society) }\end{array}$ & $\begin{array}{l}\text { Teaching } \\
\text { Council } \\
\text { registration; } \\
\text { Initial Teacher } \\
\text { Education (ITE) } \\
\text { highly regulated }\end{array}$ & & $\begin{array}{l}\text { No control } \\
\text { beyond ITE } \\
\text { as postgrad } \\
\text { professional } \\
\text { development is } \\
\text { self-funded and } \\
\text { personal choice }\end{array}$ & \\
\hline
\end{tabular}


Table 5. Control in Finland.

\begin{tabular}{|c|c|c|c|c|c|}
\hline Control : & \multirow{3}{*}{ Level } & \multirow{3}{*}{$\begin{array}{l}\text { Education } \\
\text { (planning, } \\
\text { teaching, } \\
\text { assessment) } \\
\end{array}$} & \multirow{3}{*}{$\begin{array}{l}\text { Social } \\
\text { (discipline, } \\
\text { grouping of } \\
\text { students) }\end{array}$} & \multirow{3}{*}{$\begin{array}{l}\text { Development } \\
\text { (professional } \\
\text { development) }\end{array}$} & \multirow{3}{*}{$\begin{array}{l}\text { Administration } \\
\text { (timetables, } \\
\text { resource allocation) }\end{array}$} \\
\hline $\begin{array}{l}\text { High } \\
\text { intensity }\end{array}$ & & & & & \\
\hline Low intensity & & & & & \\
\hline \multirow[t]{4}{*}{ No control } & Classroom & Principal can & School level & & \\
\hline & $\begin{array}{l}\text { (in relation to } \\
\text { students and } \\
\text { taught content) }\end{array}$ & $\begin{array}{l}\text { interfere on } \\
\text { pedagogical } \\
\text { decisions but } \\
\text { this rarely } \\
\text { happens, } \\
\text { parents' } \\
\text { involvement }\end{array}$ & $\begin{array}{l}\text { policy and } \\
\text { municipality } \\
\text { regulations } \\
\text { guide decisions }\end{array}$ & & \\
\hline & $\begin{array}{l}\text { School } \\
\text { (in relation to } \\
\text { management, } \\
\text { colleagues, } \\
\text { parents) }\end{array}$ & & $\begin{array}{l}\text { Municipality } \\
\text { regulations } \\
\text { and state } \\
\text { legislation, e.g. } \\
\text { ability groups } \\
\text { and special } \\
\text { education } \\
\text { classes }\end{array}$ & $\begin{array}{l}\text { Municipality } \\
\text { input on some } \\
\text { areas: e.g. } \\
\text { digitalisation }\end{array}$ & $\begin{array}{l}\text { Budget from } \\
\text { municipality }\end{array}$ \\
\hline & $\begin{array}{l}\text { Profession } \\
\text { (in relation to } \\
\text { actors in the } \\
\text { wider education } \\
\text { system and } \\
\text { society) }\end{array}$ & & & & \\
\hline
\end{tabular}

reported similar experiences of intensification. Tables 4 and 5 indicate how intense teachers reported control to be.Dark blue indicates high-intensity control referring to non-negotiable control imposed upon teachers. Light blue refers to control that teachers experienced but were able to negotiate somehow. White refers to either no control or no mention of control.

Focusing on the educational side of teachers' work, the differences between the two countries are considerable. Unanimously, the Finnish teachers considered the curriculum to be the most important guiding document of their pedagogical practice. However, as Finnish teachers are involved in the collaborative process of developing the school-based curriculum it is not as directive as the Irish curriculum, but rather something teachers contribute to through localisation processes. Also, in Finland there is no inspectorate body that would conduct classroom observations, publicise exam results or use any other formal direct mechanisms of control that would interfere with teachers' work at the post-primary level. In conversations concerning the absence of such formal state-directed control, and the extent to which school level practices would exist that could be considered as control, teachers were not able to give examples. For example, a teacher explains how she could not recall times when a principal would have observed her, or colleagues' lessons: 
I have been a teacher for 20 years. When I first started, I thought that principals would come in occasionally, but that must have been old information, I mean even 20 years ago . . . no one has ever come to observe my lessons for one second. (Liisa, art teacher, Koivula School)

The quote refers to the status quo characteristic of the Finnish education system that became evident in our interviews with Finnish teachers. They reported that while it is possible for the principal to interfere in teachers' pedagogical decisions, according to teachers this rarely happens. In Ireland again, the state inspectorate conducts seven different models of inspection, ranging from incidental unannounced classroom visits by a department inspector to whole-school evaluations which are usually conducted over a couple of weeks and result in the publication of a report about the school on the Department of Education and Skills website. Teachers reported how they are expected to keep detailed records of attendance, homework and assessment and a detailed scheme of work for each class group they teach, as these may be checked as part of an inspection. Individualised educational plans are also expected to be kept for students with special needs in their classes, with an emphasis on mainstreaming of all students into a mixed-ability setting.

According to the accounts Finnish and Irish teachers gave in terms of how their work is controlled, the conditions in which they work seem to be considerably different. The Irish participants reported increasing pressures from state agencies including the Teaching Council, the State Exams Commission and the Inspectorate, which have all added to teachers' individual and collective workload. In terms of classroom practice and school-level decisions, teachers report the effects that national exams, as well as the new and more frequent visits from the Inspectorate, would have on their classroom practice, as well as school-level decision-making. However, although teachers reported pressures, they were adamant in pointing out that control can be exercised in a subtle manner. The following Ashbrook teacher's comment represents the views of all participating schools:

The formal way is, I am liable to be inspected at any given time by the Department of Education in terms of the whole-school inspection, a department inspection or a fly-by. In the last academic year we've had a whole school inspection in January and we had a maths department inspection in November. So we're assessed that way. When you start off as a teacher you have to go through a process called the Droichead Programme, the new teacher mentoring where a teacher mentors you, observes your lessons, you will take a lesson and they make a judgment call on whether you're ready to be left alone. That's the formal. In terms of the informal, the management in the school can always ask to observe a class. Now, you can tell them: 'no, you don't want them to', but they can always ask. They can always ask the students and the students will be honest. They can observe through a window, they can listen. (Peter, maths and science teacher, Ashbrook Community College)

However, while control may be exercised in an indirect manner, this does not mean it is ineffective. As the above indicates (Table 4) - unless the Control tables change places in which case this (Table 5), there is a proliferation of state agencies involved in the regulatory framework in which schools operate. Certification of teaching through the creation of the Teaching Council of Ireland means that in order to be able to teach, a teacher must be a registered member of the Teaching Council, which again requires appropriate qualifications. At post-primary level, the teaching qualification required is a two-year Professional Masters in Education, which was introduced in 2015 and replaced the one-year Higher Diploma in Education postgraduate course, which existed for decades.

In addition to such direct and formal forms of control imposed externally by different state agencies or at times colleagues in more senior positions, teachers reported other, more subtle and less formal pressures. In particular, the pressures that parental involvement creates were mentioned frequently. Irish and Finnish teachers in all participating schools felt that parents were increasingly present in the day-to-day life of schools, and they explained how they found themselves explaining 
and justifying their decisions to parents in increasing measures. The feedback received from parents was described as intensive, direct and often critical and was seen as, at its most intense, a strong form of informal control. A Finnish guidance counsellor explained how she would have to defend her professional integrity and boundaries, as well as the rights of the student, from parental interference:

R: And sometimes parents will ask, could you talk to them [students] about this and that. And then you just say, no I can't.

I: How common is that?

R: Every now and then . . To tell the parents that in my job, the person to whom I listen is your child or youngster, not you. I'm sorry but the ethical basis of guidance counselling determines that the child, who is my student, is the one I listen to, but unfortunately not you. (Taru, career and guidance counsellor, Koivula School)

Irish teachers also reported increasing parental involvement and demands, specifically related to their pedagogical practice. For example:

I've probably had no complaints when I was doing Powerpoints from any parent and it's only in the last three or four years, where we have really embraced active methodologies and really got into this. I've probably had about four or five parents complain and one or two of them quite big complaints . . . you know they don't like group work, they don't want a group, they just want PowerPoints. (Elaine, history and geography teacher, Ashbrook Community College)

As teachers feel more answerable to parents and school management, paperwork evidence is a natural by-product of greater expectations of accountability. Another unifying feature emerged in that the principal greatly determines how autonomous teachers perceive themselves to be in both countries. For example, a Finnish teacher explained it like this:

The previous principal. A horrible woman, she restricted every aspect of the job . . . she breathed restriction. But our current principal is . . . say, if they say it would be good to keep a journal about a course, I will keep a journal, even though I hadn't thought to do so. (Liisa, art teacher, Koivula School)

The above statement is by a Finnish teacher, but it encapsulates the experiences teachers reported from both countries. The school leadership was seen as having a considerable effect on how teachers considered themselves able to perform in their job and in having a voice in wider school-related decisions. Related to this, it also became evident that the principals greatly buffered the wider pressures that schools were under, as they mediated the messages and directives imposed upon schools to teachers. So regardless of the system, the way in which principals involve the teaching staff in school-related decisions, and how they mediate external pressures imposed upon schools, matters for teachers' perceptions of their autonomy. There is an acceptance that the final decision in most matters rests with the principal, as they must deal with the consequences of most decisions made at school level. As one of our Irish participants put it: 'at the end of the day the buck stops with the principal. If anything goes wrong it is the principal who deals with it. And they can be put in very, very, very difficult situations' (Brendan, history and geography teacher, Ashbrook Community College). 


\section{Discussion}

To summarise, teachers in Finland and Ireland consider themselves very autonomous in their classroom practice and overall in their educational decisions. However, where much of the school-level decision-making in Finnish schools concerning educational, social and developmental issues tends to be in the hands of teachers (either collegially or as individuals), Irish teachers report that in their schools the senior management, and especially the principal, are more involved. The key issue related to decision-making is how differently Irish and Finnish teachers perceive teachers' role in student assessment; Finnish teachers considered it an important part of teachers' work, whereas the Irish teachers expressed strong unwillingness to engage in it. Indeed, the requirement that teachers assess their students' work, introduced as part of the recent Junior Cycle reform, has been a major battleground between the two main Irish second-level teaching unions and the Department of Education and Skills (O'Brien, 2016; Teachers' Union of Ireland, Association of Secondary Teachers Ireland, Department of Education and Skills, 2015). Assessment procedures go to the heart of Irish teachers' understanding of their professional autonomy and this protracted dispute, which has led to ongoing industrial action over the past few years, has only recently reached an uneasy and fragile resolution.

Rather unsurprisingly, another key difference is the ways in which teachers are controlled in the two countries and how teachers perceive such control. The Finnish-style trust-based professionalism, which equips teachers with a wide scope of action and imposes little control over their work, is in stark contrast with the Irish-style externally imposed accountability regime which, according to teachers, creates tight boundaries around certain aspects of their work. There are wider sociopolitical factors at play, as the governance regime within which teachers operate can be argued to determine to a great extent the boundaries of their professional practice. Numerous comparative studies emphasise the differences between the two governance regimes of education in western Europe: input governance and outcome governance (Benner, 2009; Hopmann 2003; Wermke et al. 2019; Wössmann, 2007). In input-governed regimes, such as Finland, teachers are considered to be civil servants holding great shared decision-making capacity, and they are subject to little if any formal forms of external control imposed upon them from outside the teaching profession. Control is exercised within the profession, and the route to the profession may be difficult, as standards of teacher education are high, and entrance tightly controlled. Teachers considered it important for the functioning of the education system, that they are assigned with important decision-making responsibilities, in which external actors do not meddle. Literature suggests that traditionally, Finnish teachers behave rather uniformly and conservatively, which is also considered to contribute to their trustworthiness (Simola, 2005). Combined with a strong occupational culture and ethos, as articulated by the Finnish teachers, control might be internalised within the profession. Finnish teachers rather unanimously argued that autonomy is good, something they should possess and something they can handle. The only critical reflections teachers presented were the high levels of stress associated with certain areas of their work (assessment in particular) and only a few teachers mentioned the possible misuse of individual autonomy. As the data reveals, teachers express in many instances that they can opt in for collegial decision-making; however, if they wish to, it seems they can also opt out. Two teachers expressed concerns about instances where a colleague had withdrawn from collective practices to the extent it had become an issue in the school. However, due to an ongoing sensitive issue in the school, teachers were not willing to discuss it in great detail. Therefore, questions such as how does a school community deal with a teacher who uses their autonomy to disengage from collegial decision-making are important, but, due to our limited data, further research is needed to reveal possible logics of such internalised control. 
In comparison, regimes which impose control upon teachers from the outside through, for example, district-level administration, state agencies or exam boards have been identified as outcomegovernance regimes. High-stakes national exams and other forms of accountability paired with a prescriptive curriculum are examples of an outcome-governance regime. Although certain features of the Irish education system suggest that it follows the logic of an output-governance regime, the reality is not clear-cut as there are contradicting forces at play. On the one hand, by introducing reforms such the Junior Cycle reform, with an emphasis on decreased and loosened standardised testing and increased teacher involvement in student assessment, as well as the Professional Masters in Education, which introduced an additional study year and a research component to teacher education, it could be argued that Ireland has taken steps to move towards an input-governance system. However, such 'imposed autonomy' as the Junior Cycle Reform brought can be interpreted as the state's attempt to shift responsibility to the teacher. Teachers' fears of 'responsibilitisation' efforts are understandable, considering the possible consequences prevalent elsewhere (Peters, 2017; Torrance, 2017). On the other hand, intensified external pressures are imposed upon the teaching profession through amplified accountability measures, such as increased and versified inspection practices. Indeed, it seems that such varied accountability mechanisms have led to teachers perceiving themselves as having decreased professional autonomy over the past years, as various stakeholders and statutory agencies exercise increased control over different aspects of teachers' work.

Conversely, neither of these attempts were received well. Irish teachers bemoaned on the one hand the intensifying outcome-governance, which has brought in new forms of external control to their work, but on the other hand they did not feel ready to let go of external control that had grasped other aspects of their work. The anxiety teachers expressed over grading their own students' work is understandable in the context of the outcome-governance regime and the shelter anonymous grading gives. The leap from all students sitting the same externally marked exams to a situation where teachers take the centre stage in evaluating their own students' work is a considerable step in reconceptualising the role of the teacher in the learning process. Collectively refusing the risks associated with grading through teacher unions, and as expressed by individual teachers in this article, Irish teachers actively bargained for a reduced form of the teaching profession: limited responsibilities, limited collective autonomy and limited risks.

Referring to Raaen's (2011) contribution to the debate, drawing on Foucault's idea of governmentalities, where teachers in particular contexts may believe they are autonomous even if they are not, may also explain teachers' responses. We might see here historically determined autonomy mindsets. Nation-specific ideas of a profession can be strongly rooted in the perceptions professionals have of themselves, and what autonomy means for them (Errs and Kalmus, 2018). For example, the extent to which external validation of (global attention to) Finnish teachers' autonomy has contributed to Finnish teachers' perceptions of their work, and has helped in creating a confident Finnish teacher arguing strongly for individual and shared collegial autonomy, is a case in point. In comparison, the Irish teachers portray a more self-restricting mindset, evident in the ways in which individual teachers as well as organised professional bodies have argued fiercely for limited teacher autonomy in the assessment debate. The extent to which such mindsets alter and determine the profession in the long run - for example, by moulding the perceptions of newly qualified and aspiring teachers - are questions worthy of further investigation.

The analysis has highlighted that recent curriculum reforms, as well as differing control regimes prevalent in both countries, have illuminated various noteworthy aspects of teacher autonomy. However, and rather surprisingly in our study, the different school governance models prevalent in the Irish education system seem to play a limited role in teachers' perceptions of their autonomy. The varied governance structures under which the Irish education system is organised bring considerable complexity to the system, which again, for the sake of standardisation, requires sophisticated 
control mechanisms. Irish participants were purposefully selected to represent different school governance models, but, almost unanimously, governance structure and ethos was not raised as an issue. While the diversity in patronage structures has implications for teachers' work, only one participant referred to the differences between secular and Catholic patronage, suggesting that the church influence has been diluted in religious-run schools over recent years. In line with existing literature on the role of Catholicism in schools we argue that this is unlikely to mean that patronage does not matter (e.g. Byrne and Devine, 2018; Grace, 2002; Sultmann and Brown, 2011), but rather that it did not concern the small sample of teachers involved in this study. Further research is needed to detect what the possible effects of religious patronage to teachers' autonomy may be.

Finally, we join the ranks of researchers arguing against surface-level comparisons and policy borrowing (Dale, 2009; Kazamias, 2009; Salokangas and Kauko, 2015; Simola and Rinne, 2011; Steiner-Khamsi, 2009) and justifying national education reforms with purpose-picked international examples (Cowen, 2000), as in the case of the Irish Junior Cycle Reform. As our study has shown, reform rhetoric calling for increased teacher autonomy in Ireland, using Finland as an example, whilst simultaneously increasing and diversifying control imposed upon teachers externally, was a textbook example of how international examples can be used somewhat misleadingly to justify national reforms.

\section{Declaration of conflicting interest}

The author(s) declared no potential conflicts of interest with respect to the research, authorship, and/or publication of this article.

\section{Funding}

The author(s) disclosed receipt of the following financial support for the research, authorship, and/or publication of this article: This work was supported by the Vetenskapsrådet.

\section{ORCID iDs}

Maija Salokangas (iD https://orcid.org/0000-0002-1646-1819

Wieland Wermke (iD https://orcid.org/0000-0003-3699-8610

\section{Note}

1. Delivering Equality of Opportunity in Schools (DEIS), the Action Plan for Educational Inclusion, was launched in May 2005 and remains the Department of Education and Skills' policy instrument to address educational disadvantage. The action plan focuses on addressing and prioritising the educational needs of children and young people from disadvantaged communities, from pre-school through second-level education (3 to 18 years) by providing a standardised system for identifying levels of disadvantage and an integrated School Support Programme (SSP). Eight hundred and twenty-five schools are included in the programme in the 2016/2017 school year: 640 primary schools (328 urban/town schools and 312 rural primary schools) and 185 second-level schools (Department of Education and Skills, 2017).

\section{References}

Benner D (2009) Schule im Spannungsfeld von Input- und Outputssteuerung [The school between the poles of input- and output governance]. In: Blömeke S, Bohl T, Haag L, et al. (eds) Handbuch Schule [Handbook of schooling]. Bad Heilbrunn: Klinkardt, pp.51-64.

Byrne R and Devine D (2018) 'Catholic schooling with a twist?': A study of faith schooling in the Republic of Ireland during a period of detraditionalisation. Cambridge Journal of Education 48(4): 461-477.

Cowen R (2009) Editorial introduction: New thinking. In: Cowen R and Kazamias M (eds) International Handbook of Comparative Education. Dordrecht: Springer, pp.961-964. 
Cribb A and Gewirtz S (2007) Unpacking autonomy and control in education: Some conceptual and normative groundwork for a comparative analysis. European Educational Research Journal 6(3): 203-213.

Dale R (2009) Contexts, constraints and resources in the development of European education space and European education policy. In: Dale R and Robertson S (eds) Globalisation and Europeanisation in Education. Oxford, UK: Symposium Books, pp.23-43.

Department of Education and Skills (2015) Source document: Framework for Junior Cycle. Dublin.

Department of Education and Skills (2017) DEIS Plan 2017: Delivering Equality of Opportunity in Schools. Dublin: DEIS. Available at: https://www.education.ie/en/Publications/Policy-Reports/DEIS-Plan-2017. pdf (accessed 25 October 2018).

Errs M (2017) Curriculum as a political and cultural framework defining teachers' roles and autonomy. In: Autio T, Hakala L and Kujala T (eds), Opetussuunnitelmatutkimus: keskustelunavauksia suomalaiseen kouluun ja opettajankoulutukseen [Curriculum research: Perspectives to Finnish school and teacher education]. Tampere: Tampere University Press, pp.193-222.

Erss M and Kalmus V (2018) Discourses of teacher autonomy and the role of teachers in Estonian, Finnish and Bavarian teachers' newspapers in 1991-2010. Teaching and Teacher Education 76: 95-105.

Finnish National Agency for Education (2018) Curriculum reform 2016: Renewal of the core curriculum for pre-primary and basic education. Available at: https://www.oph.fi/english/education_development/current_reforms/curriculum_reform_2016 (accessed 16 October 2018).

Frostensson M (2015) Three forms of professional autonomy: De-professionalisation of teachers in a new light. Nordic Journal of Studies in Educational Policy 1(2): 28464.

Gewirtz S and Cribb A (2009) Understanding Education: A Sociological Perspective. Cambridge, UK: Polity Press.

Grace G (2002) Catholic Schools: Mission, Markets, and Morality. London, UK: Routledge.

Hattie J (2011) Visible Learning for Teachers: Maxizing Impact on Learning. New York: Routledge.

Hopmann S (2015) 'Didaktik meets curriculum' revisited: Historical encounters, systematic experience, empirical limits. Nordic Journal of Studies in Educational Policy 1(1): 14-21.

Hopmann ST (2003) On the evaluation of curriculum reforms. Journal of Curriculum Studies 35(4): 459-478.

Hopmann ST (2008) No child, no school, no state left behind schooling in the age of accountability. Journal of Curriculum Studies 40(4): 417-456.

Humphreys J (2014) Junior cycle reform talks collapse despite compromise offer. The Irish Times, 11 October. Available at: https://www.irishtimes.com/news/education/junior-cycle-reform-talks-collapsedespite-compromise-offer-1.1996687

Ingersoll RM (1996) Teachers' decision-making power and school conflict. Sociology of Education 69(2): $159-176$.

Ingersoll RM (2003) Who Controls Teachers' Work? Power and Accountability in America's Schools. Cambridge, MA: Harvard University Press.

Karseth B and Sivesind K (2010) Conceptualising curriculum knowledge within and beyond the national context. European Journal of Education 45(1): 103-120.

Kazamias AM (2009) Paideia and politeia: Education, and the polity/state in comparative education. In: Cowen R and Kazamias M (eds) International Handbook of Comparative Education. Dordrecht: Springer, Dordrecht, pp.161-168.

Kosunen S (2014) Reputation and parental logics of action in local school choice space in Finland. Journal of Education Policy 29(4): 443-466.

Lubienski C (2003) Innovation in education markets: Theory and evidence on the impact of competition and choice in Charter Schools. American Education Research Journal 40(2): 395-443.

Lundgren UP (2006) Political governing and curriculum change: From active to reactive curriculum reforms. The need for a reorientation of curriculum theory. Studies in Educational Policy and Educational Philosophy 1: 1-12.

Mølstad CE (2015) State-based curriculum-making: approaches to local curriculum work in Norway and Finland. Journal of Curriculum Studies 47(4): 441-461.

Murchan D and Shiel G (2017) Understanding and Applying Assessment in Education. London: SAGE. 
National Council for Curriculum and Assessment (NCCA) (2014) Key Skills of the Junior Certificate. Dublin: NCCA.

O'Brien C (2016) ASTI votes not to co-operate with junior cycle reform. The Irish Times, 30 March. Available at: https://www.irishtimes.com/news/education/asti-votes-not-to-co-operate-with-juniorcycle-reform-1.2592706

Parker G (2015) Postmodernist perceptions of teacher professionalism: A critique. Curriculum Journal 26(3): $452-467$.

Paulsrud D and Wermke W (2019) Decision-making in Context: Swedish and Finnish teachers' perceptions of autonomy. Scandinavian Journal of Educational Research. Epub ahead of print 27 March 2019. DOI: 10.1080/00313831.2019.1596975.

Peters MA (2017) From state responsibility for education and welfare to self-responsibilisation in the market. Discourse: Studies in the Cultural Politics of Education 38(1): 138-145.

Prendergast M and Treacy P (2018) Curriculum reform in Irish secondary schools - a focus on algebra. Journal of Curriculum Studies 50(1): 126-143.

Prøitz TS, Mausethagen S and Skedsmo G (2017) Investigative modes in research on data use in education. Nordic Journal of Studies in Educational Policy 3(1): 42-55.

Raaen FD (2011) Autonomy, candour and professional teacher practice: A discussion inspired by the later works of Michel Foucault. Journal of Philosophy of Education 45(4): 627-641.

Saari A and Säntti J (2018) The rhetoric of the 'digital leap' in Finnish educational policy documents. European Educational Research Journal 17(3): 442-457.

Saari A, Tervamäki T and Värri V-M (2017) Opetussuunnitlema valtiollisen yhtenäisyyden rakentajana [Curriculum in building national cohesion]. In: Autio T, Hakala L and Kujala T (eds) Opetussuunnitelmatutkimus: keskustelunavauksia suomalaiseen kouluun ja opettajankoulutukseen [Curriculum research: Perspectives to Finnish school and teacher education]. Tampere University Press: Tampere.

Sahlberg P (2011) Finnish Lessons. What Can the World Learn from Educational Change in Finland? New York: Teachers College Press.

Salokangas M and Ainscow M (2017). Inside the Autonomous School: Making Sense of a Global Educational Trend. London: Routledge.

Salokangas M and Chapman C (2014) Exploring governance in two chains of academy schools: A comparative case study. Educational Management Administration \& Leadership 42(3): 372-386.

Salokangas M and Kauko J (2015) Borrowing Finnish PISA success? Critical reflections from the perspective of the lender. Educação e Pesquisa 41(SPE): 1353-1366.

Simola H (2005) The Finnish miracle of PISA: Historical and sociological remarks on teaching and teacher education. Comparative Education 41(4): 455-470.

Simola H and Rinne R (2011) Education politics and contingency: Belief, status and trust behind the Finnish PISA miracle. In: Pereyra MA, Kotthoff H-G and Cowen R (eds) PISA Under Examination: Changing Knowledge, Changing Tests, and Changing Schools. Rotterdam: Sense Publisher, pp.225-244.

Simola H, Varjo J and Rinne R (2011b) À contre-courant: dépendance au sentier, convergence et contingence. Vers une meilleure compréhension du modèle finlandais d'assurance-qualité et d'évaluation [Against the flow: Path dependence, convergence and contingency in understanding the Finnish QAE model]. Éducation et Sociétés: Revue internationale de sociologie de l'éducation 28(2): 35-51.

Soini T, Pietarinen J and Pyhältö K (2018) Shared sense-making strategies in curriculum reform: Districtlevel perspective. Improving Schools 21(2): 111-126.

Steiner-Khamsi G (2009) Comparison: Quo vadis? In: Cowen R and Kazamias M (eds) International Handbook of Comparative Education. Dordrecht: Springer, pp.1141-1158.

Sultmann W and Brown R (2011) Modelling pillars of Catholic school identity: An Australian study. International Studies in Catholic Education 3(1): 73-90.

Teachers' Union of Ireland, Association of Secondary Teachers Ireland, Department of Education and Skills (2015) Junior Cycle Reform: Joint Statement on Principles and Implementation. Available at: https://www.education.ie/en/Publications/Education-Reports/Junior-Cycle-Reform-Joint-Statement-onPrinciples-and-Implementation.pdf (accessed 20 October 2018). 
Torrance H (2017) Blaming the victim: Assessment, examinations, and the responsibilisation of students and teachers in neo-liberal governance. Discourse: Studies in the Cultural Politics of Education 38(1): 83-96.

Verger A and Parcerisa L (2017) A difficult relationship: Accountability policies and teachers. International evidence and key premises for future research. In: Akiba M and LeTendre G (eds) International Handbook of Teacher Quality and Policy. New York: Routledge, pp.241-254.

Wermke W and Forsberg E (2017) The changing nature of autonomy: Transformations of the late Swedish teaching profession. Scandinavian Journal of Educational Research 61(2): 155-168.

Wermke W and Höstfält G (2014) Contextualizing teacher autonomy in time and space: A model for comparing various forms of governing the teaching profession. Journal of Curriculum Studies 46(1): 58-80.

Wermke W, Olason Rick S and Salokangas M (2019) Decision-making and control: Perceived autonomy of teachers in Germany and Sweden. Journal of Curriculum Studies 51(3): 306-325.

Wilches J (2007) Teacher autonomy: A critical review of the research and concept beyond applied linguistics. Íkala, revista de lenguaje y cultura 12(18): 245-275.

Wössmann L (2007) International evidence on school competition, autonomy, and accountability: A review. Peabody Journal of Education 82(2/3): 473-497.

\section{Author Biographies}

Maija Salokangas is an assistant professor at Trinity College Dublin, School of Education. Her research explores the interplay between education policy and practice. Her recent book: Inside the Autonomous School: making sense of a global educational trend (with Mel Ainscow) critiques the international school autonomy movement.

Wieland Wermke is an associate professor at the department of special education at Stockholm University/ Sweden. His research focusses on teachers' work and professionalism from a comparative perspective.

Gerry Harvey is an assistant principal at St. Peter's College, Dunboyne, Co. Meath and a teacher of Business and Mathematics. From May 2017 to May 2019, he was an assistant professor in education with the School of Education, Trinity College Dublin and the leadership and management strand leader for their M. Ed programme. He is currently an associate member of academic staff with Trinity College Dublin. 